\title{
LINGUISTIC WORLD VIEW OF THE INDIGENOUS PEOPLES OF SIBERIA: COGNITIVE MODELLING (EXEMPLIFIED BY FRAME "MUSHROOMS") ${ }^{1}$
}

\author{
Lyudmila A. Araeva \\ Kemerovo State University, Kemerovo, Russia \\ Stanislav I. Li \\ Kemerovo State University, Kemerovo, Russia
}

\begin{abstract}
The scientific novelty of the study is determined by the fact that the propositional analysis of frames on the material of the languages of the indigenous peoples of Siberia in a comparative aspect is carried out. The frame "mushrooms" is studied in the article on the material of the languages of the indigenous peoples of Siberia (Altai, Buryat, Khakass, Shor) in comparison with the Russian language. The research is based on the frame modelling technique, which implies the analysis of underlying structures of knowledge, i.e. propositional structures. Within the framework of propositional structures, a unique way of world conceptualization by a specific nation is displayed in particular linguistic forms, in realization of proposition the influence of ethnic and cultural view of natural world is shown. The propositional analysis undertaken by the authors has enabled them to state that the frame "mushrooms" in the languages under consideration is characterized by a basic set of propositions (i.e. a mushroom is nominated according to its colour, vegetation place and time, the resemblance of another object based on a particular feature, and according to the type and result of action over it), indicates a tendency to categorize objects of natural origin based on a common family attribute. The cases of wordbuilding and propositional synonymy relations realization have been revealed and described. The conclusion states that there are distinctions in a set of propositions, which reveal the unique approach to understanding the world by a particular nation. The obtained data can be applied to teaching the languages of the indigenous peoples of Siberia.

Key worlds: languages of the indigenous peoples of Siberia, Altai language, Buryat language, Khakass language, Shor language, Russian language, propositional structure, proposition.

Citation. Araeva L.A., Li S.I. Linguistic World View of the Indigenous Peoples of Siberia: Cognitive Modelling (Exemplified by Frame "Mushrooms"). Vestnik Volgogradskogo gosudarstvennogo universiteta. Seriya 2. Yazykoznanie [Science Journal of Volgograd State University. Linguistics], 2020, vol. 19, no. 4, pp. 76-85. (in Russian). DOI: https://doi.org/10.15688/jvolsu2.2020.4.7
\end{abstract}

\section{КОГНИТИВНОЕ МОДЕЛИРОВАНИЕ ЯЗЫКОВОЙ КАРТИНЫ МИРА КОРЕННЫХ НАРОДОВ СИБИРИ (НА МАТЕРИАЛЕ ФРЕЙМА «ГРИБЫ») ${ }^{1}$}

\author{
Людмила Алексеевна Араева \\ Кемеровский государственный университет, г. Кемерово, Россия \\ Станислав Игоревич Ли \\ Кемеровский государственный университет, г. Кемерово, Россия
}

Аннотация. В статье представлены некоторые результаты исследования, научная новизна которого определяется тем, что в нем впервые осуществлен пропозициональный анализ фреймов на материале языков коренных народов Сибири в сопоставительном аспекте. В данной публикации рассматривается фрейм 
«грибы», эксплицированный в алтайском, бурятском, хакасском, шорском языках (в сопоставлении с русским). Работа базируется на методике фреймового моделирования, предполагающей обращение к глубинным пропозициональным структурам знания. В пределах таких структур реализуются пропозиции, проявляющие под влиянием конкретной языковой формы и этнокультурных особенностей уникальный способ познания мира конкретным народом. В результате пропозиционального анализа номинаций грибов установлено, что для фрейма «грибы» в изучаемых языках характерен один и тот же набор пропозиций (гриб назван по цвету, по месту произрастания, по времени произрастания, по сходству с другим объектом на основе определенного признака, по действию), которые указывают на тенденцию к категоризации предметов природного происхождения на основе общего фамильного признака. Выявлены и описаны случаи реализации отношений словообразовательно-пропозициональной синонимии. Показаны различия в наборе пропозиций и объяснены причины их возникновения. Полученные результаты могут быть использованы в процессе преподавания языков коренных малочисленных народов Сибири.

Ключевые слова: языки коренных народов Сибири, алтайский язык, бурятский язык, хакасский язык, шорский язык, русский язык, пропозициональная структура, пропозиция.

Цитирование. Араева Л. А., Ли С. И. Когнитивное моделирование языковой картины мира коренных народов Сибири (на материале фрейма «грибы») // Вестник Волгоградского государственного университета. Серия 2, Языкознание. - 2020. - Т. 19, № 4. - С. 76-85. - DOI: https://doi.org/10.15688/jvolsu2.2020.4.7

\section{Введение}

28 января 2019 г. в Париже в штаб-квартире ЮНЕСКО состоялось открытие Международного года языков коренных народов мира. Основной задачей проведенных в течение года мероприятий было сохранение находящихся под угрозой исчезновения языков. Всеобщая декларация о культурном разнообразии, принятая ЮНЕСКО в 2001 г., является правовым документом, в котором культурное разнообразие признается достоянием человечества, а его охрана - конкретным этическим обязательством, неотделимым от уважения к человеческому достоинству (URL: https:// www.un.org/ru/documents/decl conv/declarations/ cultural_diversity.shtml).

Значительным разнообразием характеризуется языковой ландшафт России. Особого исследовательского внимания требуют языки коренных народов Сибири. В статье рассматриваются шорский, алтайский, бурятский и хакасский языки. Шорский язык используется только в быту. Шорцы - тюркоязычный народ, живущий в юго-восточной части Западной Сибири, главным образом на юге Кемеровской области. Их насчитывается около 13 тысяч человек, свыше 60 \% считают родным языком русский. Алтайский, бурятский и хакасский языки, являясь языками коренных народов Сибири, сохраняются как на бытовом, так и на государственном уровне. Алтайский язык относится к тюркской языковой семье, в России насчи- тывается около 80 тысяч носителей этого языка ${ }^{2}$, они проживают преимущественно в Республике Алтай. Бурятский язык относится к монгольской ветви, в России насчитывает около 400 тысяч его носителей, они проживают преимущественно в Республике Бурятия. Хакасский язык относится к тюркской группе, в России насчитывается около 75 тысяч его носителей, они проживают преимущественно в Республике Хакасия. В Алтайской, Бурятской, Хакасской республиках государственными языками являются русский язык и алтайский, бурятский или хакасский язык соответственно. Сохранение родного языка и культурных традиций выступает первостепенной задачей в этих республиках. При этом количество носителей данных языков, как и шорского языка, стремительно сокращается. Это обусловлено тем, что для поступления в вузы России и карьерного роста необходимо хорошее знание прежде всего русского языка. В 2002 г. бурятский язык, несмотря на его государственный статус, был занесен ЮНЕСКО в список исчезающих языков. В связи с вышесказанным неслучайно, что в настоящее время государство проводит политику, направленную на сохранение национальной культуры, важное место в которой занимает концепция развития языка, призванная стать ориентиром и организационной основой решения проблемы языковой идентичности как ключевого элемента культуры и самосознания (подробнее см.: [Рупышева, 2016, с. 5]). 
В начале XIX в. В. фон Гумбольдт высказал мысль о том, что естественный язык не является абсолютно достоверным отображением мира, а отражает его творческое преобразование в процессах субъективного моделирования. По мнению немецкого филосо$\phi а$, различные языки представляют различное видение мира: «язык есть его [народа] дух, и дух народа есть его язык, и трудно представить что-то более тождественное» [Гумбольдт, 1984, с. 68]. Создание картины мира в собственной языковой вселенной позволяет человеку упорядочить свою жизнь, свободно ориентироваться в окружающем мире.

Л. Вайсгербер объясняет понятие языковой картины мира через метафору звездного неба: «Объективно данный мгновенный срез с картины мира человека состоит из столь громадного числа отдельных явлений, что он не в состоянии охватить каждое из них; лишь наиболее выдающиеся звезды получают наименование. Чтобы духовно овладеть всем остальным, человек должен некоторым образом упорядочить это множество. Так, с давних времен звезды на звездной картине неба объединяются в группы. Отдельные звезды на этой картине держатся друг за друга только благодаря некогда осуществленной и закрепленной в языке классификации, с помощью которой упорядочено ночное небо. С объективным положением и подлинными взаимоотношениями звезд на небе эта картина не имеет ничего общего. Само собой разумеется, что у разных народов эта классификация звездного неба осуществлялась различным образом» (цит. по: [Караулов, 1976, с. 244]).

При когнитивном моделировании языковой картины мира необходимо сопоставление языков разных народов, которое часто осуществляется посредством сравнительно-сопоставительного метода. Его значимость подчеркивал в своих работах Г.Д. Гачев: «Каждый новый изученный национальный тип культуры становится прожектором-объяснителем всех предыдущих: вносит поправки к предыдущим тезисам, бросает на них новый свет и добавляет им в доказательности. Каждый одновременно - и объект, и инструмент» [Гачев, 1988, с. 8].

Целью данного исследования является описание фрагмента языковой картины мира, отражающей представления коренных народов Сибири о таких природных объектах, как грибы.

\section{Материалы и методы исследования}

Для анализа взяты наиболее известные обыденному сознанию наименования таких грибов, как белый гриб, белый груздь, бледная поганка, волнушка, дождевик, лисичка, масленок, моховик, мухомор, опенок, подберезовик, подосиновик, подтопольник, рыжик, сморчок, черный груздь. У коренных народов Сибири исстари считалось, что грибы еда только для животных (оленей, белок, мышей), человек может использовать их для охоты или врачевания. В связи с этим названия грибов в исследуемых языках появились относительно поздно. У телеутов, например, сохранилось только общее наименование для всех грибов - мешке. Многие грибы шорцы, алтайцы, буряты и хакасы называют заимствованными из русского языка словами.

Материал для исследования отбирался из словарей рассматриваемых языков: «Бурятско-русского и русско-бурятского словаря» (2004), «Русско-хакасского словаря» (1961), «Русско-алтайского словаря» (1963), «Хакасско-русского словаря» (1953), «Шорско-русского и русско-шорского словаря» (1993), «Этимологического словаря тюркских языков» (1980). Для сопоставления привлекался материал русского языка, извлеченный из «Словаря русских народных говоров» и «Этимологического словаря русского языка» М. Фасмера. Кроме того, использовался материал, полученный от информантов носителей описываемых языков: алтайского языка - Керексибесовой Урсулы Валерьевны, магистранта КемГУ (Кемерово); бурятского языка - Кулеховой Анны Михайловны, учителя русского языка МБОУ СОШ № 18 (Братск); хакасского языка - Боргояковой Тамары Герасимовны, доктора филологических наук, профессора, директора института гуманитарных исследований и саяно-алтайской тюркологии Хакасского государственного университета (Абакан); шорского языка - Косточакова Геннадия Васильевича, кандидата филологических наук, 
Л.А. Араева, С.И. Ли. Когнитивное моделирование языковой картины мира коренных народов Сибири

доцента кафедры русского языка, литературы и методики преподавания НФИ КемГУ (Новокузнецк).

Для достижения поставленной цели применяется метод пропозиционально-фреймового моделирования - один из эффективных методов когнитивного анализа языка, используемый для моделирования фрагментов языковой картины мира. При анализе языковых единиц обнаруживаются пропозициональные структуры знания, представляющие собой абстрактные суждения предикативно связанных между собой актантов. В пределах пропозициональных структур (далее - ПС) реализуются пропозиции (далее - П), проявляющие под влиянием конкретной языковой формы и этнокультурных особенностей уникальный способ познания мира конкретным народом.

Одно из центральных понятий когнитивного моделирования составляет фрейм. В современной лингвистике существует три базовых подхода к исследованию фрейма лингвокогнитивный (А.Н. Баранов, А.П. Бабушкин, Е.С. Кубрякова, Дж. Лакофф, М. Минский, Н. Хомский и др.), лингвокультурологический (В.И. Карасик, В.В. Красных, В.А. Маслова и др.) и психолингвистический (Р. Абельсон, И. Гоффман и др.). Наиболее признанным в когнитивной лингвистике является понимание фрейма как относительно самостоятельной структуры организации знаний и опыта человека в стереотипной ситуации. Мы анализируем фрейм с лингвокогнитивных и лингвокультурных позиций. При этом фрейм определяется как пропозиционально организованный фрагмент языковой картины мира. Конкретные стереотипные ситуации (пропозиции) реализуются в пределах пропозициональных структур знаний, направляющих мысль человека при отражении в языке (в его лексических единицах) представлений о действительности. В рамках Кемеровской дериватологической школы данные структуры рассматриваются как наиболее абстрактные суждения с предикативно связанными актантами, указывающими на место, время, средство, цель, объект действия субъекта; результат по средству, месту, субъекту изготовления; субъект, имеющий отношение к другому субъекту, место по объекту назначения, времени использования и т. п. [Араева и др., 2016, с. 79].

Метод пропозиционально-фреймового моделирования апробирован представителями Кемеровской дериватологической школы (КемГУ) при сборе языкового материала и описании языковой картины мира бесписьменного языка коренного народа Сибири - телеутов, а также русского литературного языка и русских народных говоров (за 30 лет проведения исследований в данном направлении опубликовано более 1000 научных работ).

\section{Результаты и обсуждение}

$$
\begin{gathered}
\text { ПС «объект - признак», } \\
\text { П «гриб по цвету» }
\end{gathered}
$$

Русский язык: по цвету обозначаются бельй гриб, белый груздь, черный груздь, рыжжик; волнушки названы как по форме, так и по цвету шляпки - краснуха; дождевик в русских говорах именуют не только по времени появления, но и по цвету шляпки - белыш: «Белыш. Гриб-дождевик» (СРНГ, вып. 2, с. 234).

Алтайский язык: белые грибы называют ак мешке (ак - белый, мешке - гриб); рыжик - сары мешке (сары - желтый, мешке - гриб); черный груздь - кара мешке (кара - черный, мешке - гриб).

Бурятский язык: по цвету названы белый гриб - саган моогэ (сагаан - белый, моогэ - гриб), саган һархяаг (сагаан - белый, hархяаг - гриб); масленок - шара моогэ (щара - желтый, моогэ - гриб); рыжик - шара hархяаг (шара - желтый, hархяаг - гриб), шарлуу (шар - рыжий; луу суффикс сущ.); сморчок - хара моогэ (хара - черный, моогэ - гриб); по цвету шляпки назван подосиновик - улаан толгойто һархяаг, «красноголовый гриб».

Хакасский язык: белый гриб - ах миске (ax - белый, миске - гриб); масленок кӥрец миске (кӱрещ - коричневый, миске гриб); рыжик - сарыгмиске (сарыг- желтый, миске - гриб).

Шорский язык: белый гриб - ақұмешке (ак--белый, мешке - гриб); подосиновик кызыл мешке (кызыл - красный, мешке гриб). 


\section{ПС «объект - предикат - место», П «гриб, растущий в определенном месте»}

Русский язык: боровик - «гриб, растущий в бору»; моховик - «гриб, растущий во мху»; опенок - «гриб, растущий на пне»; подберезовик - «гриб, растущий под березой»; подосиновик - «гриб, растущий под осиной»; подтопольник - «гриб, растущий под тополем».

Алтайский язык: дождевик - am сидик (am - лошадь, сидик - моча). Такое название связано с тем, что на Алтае дождевики растут там, где пасутся лошади, то есть в данном случае при характеристике места произрастания дождевиков для алтайцев, которые занимаются коневодством, значимо указание на запах, являющийся результатом физиологических выделений лошадей. Подберезовик кайьн нмешке (кайы н- береза, мешке - гриб), «гриб, растущий под березой»; подосиновикаспак мешке (аспак - осина, мешке - гриб), «гриб, растущий под осиной».

Бурятский язык: подосиновик - уляастай (уляас - осина, тай - суффикс сущ.), «гриб, растущий под осиной».

Хакасский язык: волнушка-тыт мискезі (тыл - лиственница, мискезі - гриб), «гриб, растущий под лиственницей»; груздь - тирек мискезі (тирек - тополь, мискезі - гриб), «гриб, растущий под тополем»; опенок - тјкпес мискезі (тјкпес-пень, мискезі-гриб), «гриб, растущий на пне»; подберезовик - хазыцимискезі (хазыц̧береза, мискезі - гриб), «гриб, растущий под березой»; подосиновик - ос мискезі (ос - осина, мискезі - гриб), «гриб, растущий под осиной»; рыжик - харагай мискезі (харагай - сосна, мискезі - гриб), «гриб, растущий под сосной».

Шорский язык: груздь / подтопольник терек мешке (терек - тополь, мешке - гриб), «гриб, растущий под тополем»; подберезовик - қазыц мешке (қазыц - береза, меш-

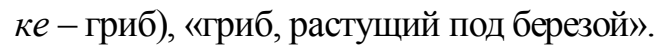

\section{ПС «объект, по характерному признаку объекта ${ }_{2}$, \\ П «гриб, напоминающий другой объект по определенному признаку"}

Русский язык: гриб лисичка метафорически ассоциируется с цветом меха лисы; масленок - гриб с маслянистой, скользкой на ощупь шляпкой; дождевик в русских народных говорах называют порховка «гриб, по результату воздействия напоминающий порох»; пылевик - «гриб, по результату воздействия напоминающий пыль» (эти номинации можно объяснить тем, что у созревших грибов образуется порошковая масса спор, которая напоминает по цвету и консистенции пыль); табачный гриб - «гриб, который по цвету и консистенции напоминает табак»: «Порховки (грибы) не едят, пыль из нее. Порховка, как яичко куриное, а потом с голову разрастается. После дождя выходит дым из нее желтый. Смаслом, сметаной смешаешь и от чирьев (прикладываешь). Краснояр. Енис. У, чево дожжовиков-то! После все порховки будут, как разорвешь ее да подавишь, дак ровно дым из ее пойдет. Перм. Вят.» (СРНГ, вып. 30, с. 113).

Алтайский язык: лисичка - айак мешке (айак - чашка, мешке - гриб), «гриб, по форме шляпки напоминающий чашку»; масленок - јыллырыл мешке (јылјырык - слякоть, мешке - гриб), «гриб, по внешнему виду напоминающий слякоть».

Бурятский язык: волнушки - долгоёодой (долг - волна, ёодой - уменьшительно-ласкательный суффикс сущ.), «гриб, узор на шляпке которого напоминает волны»; масленок - тоһолиг (тоһо - масло, лиг - суффикс сущ.), «гриб, по внешнему виду напоминающий масло».

Хакасский язык: все белые грибы называются сйт миске (сӥm - молоко, миске гриб), «грибы, по цвету напоминающие молоко»; волнушка - nозы д миске (nозы гвоздь, миске - гриб), «гриб, по внешнему виду напоминающий гвоздь»; груздь - чаг миске (чаz - сало, миске - гриб), «гриб, по вкусу напоминающий сало»; лисичка ассоциируется с цветом меха лисы - тӥлгй мискезі

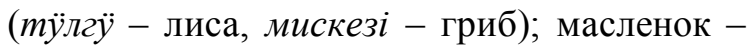
іріңучі миске (іріщ̧џі - сопли, миске - гриб), «гриб, по внешнему виду напоминающий сопли»; опенок - салаа миске (салаа - палец, миске - гриб), «гриб, по внешнему виду напоминающий палец».

Шорский язык: данная ПС не реализуется. 
Л.А. Араева, С.И. Ли. Когнитивное моделирование языковой картины мира коренных народов Сибири

\section{ПС «объект - действие», П «гриб по его действию»}

Русские язык: дождевик - бздушка, пердунок, пукалка. Эти номинации указывают на разлетающиеся при прикосновении к грибу неприятные на запах споры. «Пердунок, нка, м. Ласк. Небольшой белый гриб. Набрали свиней да пердунков. Смол. 1914» (СРНГ, вып. 26, с. 19); «Бздушка. Род шарообразного гриба, наполненного пылью, похожею с виду на нюхательный табак (СРНГ, вып. 2, с. 287).

Алтайский язык: бледная поганка корон мешке (корон - ядовитый, мешке гриб), «ядовитый гриб». Этот гриб вызывает тяжелое отравление, которое приводит к смерти в течение десяти дней.

Хакасский язык: бледная поганка - чут миске (чут - истощать, миске - гриб), «гриб, который истощает»; мухомор - ӧдірчеи миске (ӧдірчен - убивать, миске - гриб), «убивающий гриб».

Бурятский, шорский языки: данная ПС не реализуется.

\section{ПС «объект - предикат - время", П «гриб, растущий \\ в определенное время"}

Русский язык: дождевик - громовик «гриб, растущий после грома»; дождевик «гриб, который появляется после дождя».

Бурятский язык: дождевик - хураша (хур - дождь, аша - суффикс сущ.), «гриб, который появляется после дождя».

Хакасский язык: дождевик - наумыр мискезі (наумыр - дождь, мискезі - гриб), «гриб, который появляется после дождя».

Алтайский, шорский языки: данная ПС не реализуется.

\section{ПС «объект - признак»,}

\section{П «гриб по издаваемому запаху»}

Алтайский язык: мухомор - јыду мешке (јылду - вонючий, мешке - гриб), «гриб, который воняет».

Бурятский, хакасский, шорский, русский языки: данная ПС не реализуется.
ПС «объект - признак»,

\section{П «гриб по способу произрастания»}

Алтайский язык: опенок - биле мешке (биле - семья, мешке - гриб), «гриб, который растет семьей» (номинация связана с тем, что опята растут большими группами).

Бурятский, хакасский, шорский, русский языки: данная ПС не реализуется.

$$
\begin{gathered}
\text { ПС «объект } 1 \text { - предикат - признак } \\
\text { объекта } ", ~ \\
\text { П «гриб по своей структуре» }
\end{gathered}
$$

Бурятский язык: дождевик - тэнгэриин тамхин («небесный табак»).

Алтайский, хакасский, шорский, русский языки: данная ПС не реализуется.

\section{ПС «объект - предикат - средство», П «гриб как средство»}

Бурятский язык: дождевик - тэнгэриин дүлии («глухота неба»). Бурятские охотники в безветренную погоду по движению спор гриба определяли направление внешне неощутимого ветра, что помогало им подойти к зверю незамеченными.

Алтайский, хакасский, шорский, русский языки: данная ПС не реализуется.

\section{Выводы}

В каждом из языков коренных народов Сибири для номинации грибов используется суффиксоид, выражающий обобщенное значение «гриб»: в алтайском и шорском - меш$\kappa е$, в бурятском - моогэ и һархяаг, в хакасском - миске, мискезі. Аналогичные тенденции номинации наблюдаются в этих же языках при именовании ягод [Араева, Ли, 2019].

Проанализировав наименования грибов в разных языках, мы можем восстановить представления о грибах в сознании носителей языков коренных народов Сибири, понять, по каким признакам их категоризуют.

Грибы, как правило, обозначаются по одному из признаков, однако этот признак никак не предопределяет иные признаки грибов. Например, наименование гриба по времени 
произрастания (дождевик, громовик) никак не предопределяет цвет шляпки гриба, место произрастания, форму шляпки или ножки. Грибы могут именоваться не только по визуально воспринимаемому признаку (цвет, размер, форма, место произрастания), но и по прагматической значимости (способ приготовления, съедобность или несъедобность). При этом признаки, положенные в основу именования грибов, ограничиваются жизненным опытом человека. Несмотря на то что для одного этноса актуальным является цвет и форма шляпки, для другого - время произрастания и форма ножки, для третьего - запах гриба и способ произрастания, в семантике производных слов, обозначающих грибы, актуализируется целый ряд пропозиций, формирующих общий фрейм.

В названиях одного и того же объекта действительности в рамках реализации одной пропозиции может проявляться специфика. Так, цвет, лежащий в основе наименования гриба, может варьироваться в пределах одной цветовой гаммы. Например, гриб рыжик в алтайском, бурятском и хакасском языках - это гриб желтого цвета, а для носителя русского языка - рыжий гриб. Маслята в бурятском языке - желтые грибы, в хакасском - коричневые.

Носитель языка в момент называния какой-либо реалии связывает ее с другими объектами действительности по какому-то сходному признаку. Такой признак может быть специфичным для конкретного этноса. Например, русские и буряты гриб масленок из-за его скользкой шляпки сравнивают с маслом, алтайцы - со слякотью, а хакасы - с соплями. Русские и хакасы ассоциируют гриб лисичку с цветом меха лисы, алтайцы этот гриб называют по форме шляпки гриба, напоминающей чашку. Волнушка в русском и бурятском языках названа по волнистому узору на шляпке, в хакасском - по форме гвоздя.

Один и тот же гриб может называться по разным основаниям. При этом в разных языках признаки, по которым происходит процесс наименования, могут варьироваться. Для одних народов становится важным цвет шляпки гриба, время его роста и результат воздействия на него, для других - цвет гриба и то, как этот гриб можно использовать в ка- ком-либо промысле. Например, в русском языке дождевик называют не только по времени роста (после дождя), но и по результату воздействия (порховка, пылевик) и цвету (белылш). Буряты этот же гриб, как и русские, называют по времени произрастания (хураша: $x y p$ - дождь, аша - суффикс сущ.), однако они также используют этот гриб во время охоты для отслеживания добычи, отсюда еще одна номинация - тэнгэриин дүлии («глухота неба»). В хакасском и бурятском языках маслята имеют по два наименования: по цвету шляпки - в хакасском: кӥрецц (кӥрещ - коричневый, миске - гриб), в бурятском: шара моогэ (шара - желтый, моогэ - гриб) и по характерному признаку другого объекта в хакасском: іріңџі миске (іріңчі - сопли, миске - гриб), в бурятском: тоһолиг (moho масло, лиг - суффикс сущ.).

Исследуя один и тот же объект в разных языках, мы обнаружили реализацию отношений словообразовательно-пропозициональной синонимии (далее-СПС), проявляющей стремление познающего человека с помощью дискретных единиц представить многосторонний образ этого объекта. СПС можно считать «системным явлением, эксплицирующим взаимодействие типов на уровне фрейма через разные ЛСЗ (пропозиции), сформированные пропозициональными структурами знаний» [Араева, 2015, с. 163]. Как показано А.А. Шумиловой, «в языковой картине мира через словообразовательно-пропозициональную синонимию представлена многоплановая характеристика познаваемого объекта (реализованная через характеризующие словообразовательно-пропозициональные значения), множественность возможных ситуаций функционирования этого объекта (реализованные через функциональные словообразовательно-пропозициональные значения)» [Шумилова, 2012, с. 237].

СПС, характерная для описываемых языков, имеет в каждом из них свои особенности, проявляя особенности восприятия одного и того же гриба разными этносами. Например, в русском языке образуется такой синонимичный ряд при именовании дождевика: дождевик - громовик - бельиш - порховик пердунок - пукалка - табачный гриб. В бурятском языке наряду с употребляемым русским именованием дождевик существует на- 
звание этого гриба, обусловленное культурными традициями: тэнгэриин д үлии («глухота неба»). В хакасском языке наряду с русским названием гриба груздь существует синоним этого имени - чад миске «гриб, по вкусу напоминающий сало». В хакасском языке $p ы-$ жик именуется по цвету (сарыз миске), как и в русском языке, и по месту произрастания (харагай мискезі «гриб, растущий под сосной»), что обусловлено особенностями территории, на которой произрастает этот гриб. В хакасском наряду с русским названием гриба волнушка используется имя тыт мискезі «гриб, растущий под лиственницами», что обусловлено особенностью климата и территории Хакассии, где растут лиственницы. В алтайском языке наряду с русским названием гриба рыжик используется синонимичное алтайское слово сары мешке.

Словообразовательно-пропозициональные синонимы, характерные для определенного этноса, проявляют стремление человека с помощью дискретных единиц представить с разных сторон образ того или иного гриба. Говорящий в зависимости от цели коммуникации может выбрать то или иное слово или словосочетание. По мнению Н.Д. Арутюновой, «возможность пользоваться разными именами для обозначения одного и того же конкретного предмета создает ситуации, которые можно назвать гетерономинативными. Гетерономинативность может быть следствием предицирующих возможностей номинаций, пользуясь которыми говорящий одновременно идентифицирует предмет речи для собеседника, сообщает о нем дополнительные сведения и дает ему оценку» [Арутюнова, 1999, с. 97].

Ассимиляция коренных малочисленных народов Сибири с русским населением обусловила возникновение смешанной синонимии, что видно из приведенных в статье примеров.

Кроме синонимии номинаций специфика проявляется в актуализации той или иной пропозиции. Так, в отличие от других исследуемых языков, в алтайском языке в номинации дождевика актуализируется признак места произрастания грибов, где пасутся кони. Только в алтайском языке в наименовании мухомора реализованы ПС «объект - признак», П «гриб по издаваемому запаху»: jылуу мешке (jыду вонючий, мешке - гриб), «гриб, который воня- ет». Только алтайцы называют опята по способу произрастания (ПС «объект - признак», П «гриб по способу произрастания»): билемемке (биле - семья, мешке - гриб), «гриб, который растет семьей». Только в бурятском языке реализованы ПС «объект ${ }_{1}$ - предикат - признак объекта 2 », П «гриб по своей структуре» и ПС «объект - предикат - средство», П «гриб как средство». Буряты раньше не употребляли грибы в пищу, а использовали их как лекарство или как инструмент во время охоты: гэриин тамхин («небесный табак») и тэнгэриин дүлии («глухота неба»).

\section{Заключение}

Таким образом, для фрейма «грибы» в исследуемых языках характерен базовый набор пропозиций: гриб по цвету; гриб, растущий в определенном месте; гриб, напоминающий другой объект по определенному признаку; гриб по его действию; гриб, растущий в определенное время. Они выступают ориентиром и точкой соприкосновения мира идей и мира вещей, указывают на тенденцию к категоризации предметов природного происхождения на основе общего фамильного признака. При этом обнаруживаются и особенности реализации пропозиций. На то, какой признак ляжет в основу номинации, влияет множество факторов, основные из них - природно-климатические, территориальные, пищевая культура конкретного народа, количество носителей языка и др. В этом и заключается уникальность языковой картины мира каждого народа.

Полученные результаты могут найти применение в процессе преподавания языков коренных малочисленных народов. Пропозиционально-фреймовый метод позволяет включить языки малых народов в общелингвистический контекст, дает возможность обучающимся, проникая в семантику производного слова, во-первых, осмыслить этапы номинации, которые прошел какой-либо объект действительности в сознании носителя языка, а именно: этап классификации и категоризации, этап связывания одного предмета с другим посредством ассоциаций, этап создания новых слов по аналогии и т. д., а во-вторых, понять общие закономерности познания мира представителями разных народов. 


\section{ПРИМЕЧАНИЯ}

${ }^{1}$ Исследование выполнено при финансовой поддержке РФФИ в рамках научного проекта № 19312-90003 «Когнитивное моделирование языковой картины мира коренных народов Сибири (на материале имен натурфактов)».

The research was funded by Russian Foundation for Basic Research, project number 19-312-90003 "Cognitive modelling of linguistic world view of the indigenous peoples of Siberia (on the names of natural objects)"

2 Здесь и далее сведения о количестве носителей языка приводятся по данным переписи населения России 2010 г. (URL: https://www.gks.ru/free_doc/ new_site/perepis2010/croc/perepis_itogil612.htm).

\section{СПИСОК ЛИТЕРАТУРЫ}

Араева Л. А., 2015. Одна из самых загадочных сфер языка (к вопросу о словообразовательно-пропозициональной синонимии) // Язык в пространстве речевых культур : К 80-летиюВ.Е. Гольдина. М. ; Саратов : Амирит. С. 154-164.

Араева Л. А., Калентьева Л. С., Кузнецова В. С., Тагаев М. Дж. 2016. Пропозициональная организация терминов некровного родства в телеутском, киргизском и китайском языках // Вестник Кемеровского государственного университета. № 3. С. 79-86. DOI: https:// doi.org/10.21603/2078-8975-2016-3-79-85.

Араева Л. А., Ли С. И., 2019. Метод пропозиционально-фреймового моделирования в обучении иностранным языкам // Вестник Волгоградского государственного университета. Серия 2, Языкознание. Т. 18, № 1. С. 187-195. DOI: https://doi.org/10.15688/jvolsu2.2019.1.16.

Аругюнова Н. Д., 1999. Язык и мир человека. М. : Яз. рус. культуры. XV, 896 с.

Гачев Г. Д., 1988. Национальные образы мира. М. : Сов. писатель. 233 с.

Гумбольдт В. фон, 1984. О различии строения человеческих языков и его влиянии на духовное развитие человечества // Избранные труды по языкознанию. М. : Прогресс. С. 37-297.

Караулов Ю. Н., 1976. Общая и русская идеография. М. : Наука. 356 с.

Рупышева Л. Э., 2016. Названия растений бурятского языка : (Флоронимическая лексика). Улан-Удэ : Изд-во Вост.-Сиб. гос. ин-та культуры. 185 с.

Шумилова А. А., 2012. Фреймовое моделирование словообразовательно-пропозициональной синонимии (на материале диалектной лексики Кемеровского района) // Вестник Кемеровского государственного университета. Т. 4, № 4. С. 236-239.

\section{СЛОВАРИ}

СРНГ - Словарь русских народных говоров. Вып. 1- . М. ; Л. ; СПб : Наука, 1965- . Вып. 2 / под ред. Ф. П. Филина. Л. : Наука, 1966. 317 с. ; вып. 26 / под ред. Ф. П. Сороколетова. Л. : Наука, 1991. 351 с. ; вып. 30 / под ред. Ф. П. Сороколетова. СПб. : Наука, 1996. 385 с.

Бурятско-русский и русско-бурятский словарь / под ред. С. М. Бабушкина. Улан-Удэ : Респ. тип., $2004.568 \mathrm{c}$.

Русско-алтайский словарь / под. ред. Н. А. Баскакова. М. : Сов. энцикл., 1963.875 с.

Русско-хакасский словарь / под ред. Д. И. Чанкова. М. : ГИИНС, 1961.968 c.

Фасмер М. Этимологический словарь русского языка : в 4 т. / пер. с нем и доп. О. Н. Трубачева ; под ред. и с предисл. Б. А. Ларина. М. : Прогресс, 1986-1987. 4 т.

Хакасско-русский словарь / под ред. Н. А. Баскакова. М. : Гос. изд-во иностр. и нац. слов., 1953. 487 с.

Шорско-русский и русско-шорский словарь / сост.: Н. Н. Курпешко-Таннагашева, Ф. Я. Апонькин. Кемерово : Кемер. кн. изд-во, 1993. 147 с.

Этимологический словарь тюркских языков / сост. Э. В. Севортян. М. : Наука, 1980. 395 с.

\section{REFERENCES}

Araeva L.A., 2015. Odna iz samykh zagadochnykh sfer yazyka (k voprosu o slovoobrazovatelnopropozitsionalnoy sinonimii) [One of the Most Mysterious Spheres of the Language (On the Issue of Word-Formation-Propositional Synonymy)]. Yazyk v prostranstve rechevykh kultur: K 80-letiyu V.Ye. Goldina [Language in the Space of Speech Cultures: To the $80^{\text {th }}$ Anniversary of V.E. Goldin]. Moscow, Saratov, Amirit Publ., pp. 154-164.

Araeva L.A., Kalentieva L.S., Kuznetsova V.S., Tagaev M.J., 2016. Propozitsionalnaya organizatsiya terminov nekrovnogo rodstva $\mathrm{v}$ teleutskom, kirgizskom $\mathrm{i}$ kitayskom yazykakh [Propositional Organization of the Terms of In-Law Relationships in the Teleut, Kirghiz and Chinese Languages]. Vestnik Kemerovskogo gosudarstvennogo universiteta [Bulletin of Kemerovo State University], no. 3, pp. 79-86. DOI: https://doi.org/10.21603/20788975-2016-3-79-85.

Araeva L.A., Li S.I., 2019. Metod propozitsionalnofreymovogo modelirovaniya $\mathrm{v}$ obuchenii inostrannym yazykam [The Method of the Propositional Frame Modeling in Teaching a Foreign Language]. Vestnik Volgogradskogo gosudarstvennogo universiteta. Seriya 2, Yazykoznanie [Science Journal of Volgograd State 
Л.А. Араева, С.И. Ли. Когнитивное моделирование языковой картины мира коренных народов Сибири

University. Linguistics], vol. 18, no. 1, pp. 187-195. DOI: https://doi.org/10.15688/jvolsu2.2019.1.16.

Arutyunova N.D., 1999. Yazyk i mir cheloveka [Language and the World of Man]. Moscow, Yazyki russkoy kultury Publ. XV, 896 p.

Gachev G.D., 1988. Natsionalnye obrazy mira [National Views of the World]. Moscow, Sovetskiy pisatel Publ. 233 p.

Gumboldt V. fon, 1984. O razlichii stroeniya chelovecheskikh yazykov i ego vliyanii na dukhovnoe razvitie chelovechestva [On Language: The Diversity of Human LanguageStructure and Its Influence on the Mental Development of Mankind]. Izbrannye trudy po yazykoznaniyu [Selected Works on Linguistics]. Moscow, Progress Publ., pp. 37-297.

Karaulov Yu.N., 1976. Obshchaya i russkaya ideografiya [General and Russian Ideography]. Moscow, Nauka Publ. 356 p.

Rupysheva L.E., 2016. Nazvaniya rasteniy buryatskogo yazyka: (Floronimicheskaya leksika) [Names of Plants of the Buryat Language (Floronimic Vocabulary)]. Ulan-Ude, Izd-vo VostochnoSibirskogo gosudarstvennogo instituta kultury. $185 \mathrm{p}$.

Shumilova A.A., 2012. Freymovoe modelirovanie slovoobrazovatelno-propozitsionalnoy sinonimii (na materiale dialektnoy leksiki Kemerovskogo rayona) [Frame-Based Modelling of Word Formation Propositional Synonymy (Based on the Dialect Vocabulary of the Kemerovo District)]. Vestnik Kemerovskogo gosudarstvennogo universiteta [Bulletin of Kemerovo State University], vol. 4, no. 4, pp. 236-239.

\section{DICTIONARIES}

Slovar russkikh narodnykh govoro $v$ [Dictionary of Russian Folk Dialects]. Iss. 2. Leningrad, Nauka Publ., 1966. 317 p.; iss. 26. Leningrad, Nauka Publ., 1991. 351 p.; iss. 30. Saint Petersburg, Nauka Publ., 1996. 385 p.

Babushkin S.M., ed. Buryatsko-russkiy i russkoburyatskiy slovar [Buryat-Russian and RussianBuryat Dictionary]. Ulan-Ude, Respublikanskaya tipografiya, 2004. 568 p.

Baskakov N.A., ed. Russko-altayskiy slovar [RussianAltai Dictionary]. Moscow, Sovetskaya entsiklopediya Publ., 1963. 875 p.

Chankov D.I., ed. Russko-khakasskiy slovar [RussianKhakas Dictionary]. Moscow, GIINS Publ., 1961. $968 \mathrm{p}$.

Fasmer M. Etimologicheskiy slovar russkogo yazyka: $v 4 t$. [Etymological Dictionary of the Russian Language. In 4 Vols.]. Moscow, Progress Publ., 1986-1987.

Baskakov N.A., ed. Khakassko-russkiy slovar [Khakass-Russian Dictionary]. Moscow, Gosudarstvennoe izd-vo inostrannykh i natsionalnykh slovarey, 1953. $487 \mathrm{p}$.

Kurpeshko-Tannagasheva N.N., A ponkin F.Ya., eds. Shorsko-russkiy i russko-shorskiy slovar [Shor-Russian and Russian-Shor Dictionary]. Kemerovo, Kemerovskoe knizhnoe izd-vo, 1993. 147 p.

Sevortyan E.V., ed. Etimologicheskiy slovar tyurkskikh yazykov [Etymological Dictionary of the Turkic Languages]. Moscow, Nauka Publ., $1980.395 \mathrm{p}$.

\section{Information About the Authors}

Lyudmila A. Araeva, Doctor of Sciences (Philology), Professor, Head of the Department of Stylistics and Rhetoric, Kemerovo State University, Krasnaya St, 6, 650000 Kemerovo, Russia, araeva@list.ru, https://orcid.org/0000-0002-7907-3186

Stanislav I. Li, Postgraduate Student, Assistant Lecturer, Department of Stylistics and Rhetoric, Kemerovo State University, Krasnaya St, 6, 650000 Kemerovo, Russia, li.stanislav999@yandex.ru, https://orcid.org/0000-0003-0576-0511

\section{Информация об авторах}

Людмила Алексеевна Араева, доктор филологических наук, профессор, заведующая кафедрой стилистики и риторики, Кемеровский государственный университет, ул. Красная, 6, 650000 г. Кемерово, Россия, araeva@list.ru, https://orcid.org/0000-0002-7907-3186

Станислав Игоревич Ли, аспирант, ассистент кафедры стилистики и риторики, Кемеровский государственный университет, ул. Красная, 6, 650000 г. Кемерово, Россия, li.stanislav999@yandex.ru,https://orcid.org/0000-0003-0576-0511 